\title{
DEVELOPMENT AND VALIDATION OF DISPERSIVE LIQUID-LIQUID MICROEXTRACTION FOR THE DETERMINATION OF MULTICLASS PESTICIDE RESIDUES IN COMPLEX FOOD MATRIX
}

\author{
Livien Khor ${ }^{1}$ and Mee Kin Chai ${ }^{2 *}$
}

${ }^{1}$ Dept. of Industrial Science, College of Graduate School, Universiti Tenaga Nasional, Jalan IKRAM-UNITEN, 43000 Kajang, Selangor, Malaysia.

${ }^{2}$ Dept. of Civil Engineering, College of Engineering, Universiti Tenaga Nasional, Jalan IKRAM-UNITEN, 43000 Kajang, Selangor, Malaysia. mkchai@ uniten.edu.my (corresponding author)

\begin{abstract}
In this study, dispersive liquid-liquid microextraction (DLLME) which is known for its simplicity, rapidity and high recovery was developed coupling with gas chromatography-flame ionization detector (GC-FID) for the determination of pesticides of different chemical groups in tomato and cucumber samples. Parameters affecting the extraction efficiency of DLLME such as types and volume of extraction solvent and dispersive solvent, extraction time and ionic strength of aqueous solution were studied and optimized. Under the optimized conditions $(0.8 \mathrm{~mL}$ acetone, dispersive solvent; $14.2 \mu \mathrm{L}$ tetrachloroethylene, extraction solvent; $20 \mathrm{~s}$ extraction time; no salt addition), the relative recoveries of pesticides from tomato and cucumber samples at a dilution factor of 1:25 were in the range of $94.58-103.34 \%$ and $96.46-109.45 \%$ respectively. The limits of detections (LODs) of all pesticides except diuron from tomato and cucumber extracts were ranged from $7.5-15 \mu \mathrm{g} / \mathrm{L}$ and $15-39 \mu \mathrm{g} / \mathrm{L}$ respectively. All the LODs of pesticides except diuron extracted from both tomato and cucumber extracts using the proposed DLLME method coupled with GC-FID were still found to be lower than the maximum residue levels (MRLs) established by European Union and / or Codex Alimentarius.
\end{abstract}

ABSTRAK Dalam kajian ini, pengekstrakan mikro cecair-cecair serakan (DLLME) yang terkenal dengan keringkasan, kepantasan dan pemulihan yang tinggi telah dibangunkan gandingan dengan gas kromatografipengesan pengionan api $(G C-F I D)$ untuk penentuan racun perosak beraneka kumpulan kimia dalam sampel tomato dan timun. Parameter yang mempengaruhi kecekapan pengekstrakan DLLME seperti jenis dan isipadu pelarut pengekstrakan dan pelarut penyebar, masa pengekstrakan serta kekuatan ionic larutan akueus dikaji dan dioptimumkan. Di bawah syarat-syarat yang optimum $(0.8 \mathrm{~mL}$ aseton, pelarut penyebar; $14.2 \mu \mathrm{L}$ tetrakloroetilena, pelarut pengekstrakan; $20 \mathrm{~s}$ masa pengekstrakan; tiada tambahan garam), relative pemulihan racun perosak daripada sampel tomato dan timun dengan factor pencairan 1:25 adalah dalam lingkungan $94.58-103.34 \%$ dan 96.46 - 109.45\% masing-masing. Had pengesanan (LODs) bagi semua racun perosak yang diekstrak daripada tomato dan timun kecuali diuron dengan menggunakan kaedah DLLME bergandingan dengan GC-FID yang dicadangkan masih didapati lebih rendah daripada tahap maksimum sisa baki racun perosak yang ditetapkan oleh European Union dan/ atau Codex Alimentarius.

Keywords: Dispersive liquid-liquid microextraction, gas chromatography-flame ionization detector, pesticides, tomato and cucumber extracts

\section{INTRODUCTION}

Rising awareness of public to the health hazards posed by pesticide residues in fruits and vegetables has spurred the development of many high selectivity and sensitivity analytical methods. Conventional extraction method such as liquidliquid extraction (LLE) and solid-phase extraction (SPE) have been used as basic methods of analysis for many years. However, both are said to be laborintensive and tedious [1]. Thus, recent research has been focused on the development of more efficient,economical and environmental friendly miniaturized sample preparation methods like solidphase microextraction (SPME), single-drop microextraction (SDME) and liquid-phase microextration (LPME). However, each of these methods has its disadvantages such as the limited lifetime of the fiber of SPME [2], the drop dislodgement in SDME [3] and the long extraction time in LPME [4]. Dispersive liquid-liquid microextraction (DLLME) was first introduced by Razaee and co-workers in 2006 to determine polyaromatic hydrocarbons (PAHs) in water samples [5]. In this method, an appropriate mixture of water- 
immiscible organic extraction solvent dissolved in a water-miscible dispersive solvent is injected rapidly into an aqueous sample. A cloudy solution which consists of fine droplets of extraction solvents dispersing in the aqueous solution is formed. The infinitely large contact surface between the extraction solvent and the aqueous sample has led to the fast analytes-extraction. As a result, very short extraction time has become the key advantage of this new extraction method. Besides, DLLME is reported to provide the advantages of simplicity of operation, rapidity, low-cost, high recovery, high enrichment factor and environment benignity [56].For the past few years, DLLME coupling with gas chromatography (GC) or liquid chromatography (LC) has been used to analyse PAHs [5, 7-8], polychlorinated biphenyls (PCBs) [9-10], drugs [1113], herbicides [14], organophosphorus pesticides (OPP) [6, 15], organochlorine pesticides (OCP) [1] in environmental, biological as well as food and beverage samples.

However to date, there is no published report regarding simultaneous determination of pesticides from different chemical groups using DLLME method coupled with GC-FID in samples from complex matrices like vegetables. The aim of this study is to evaluate the suitability of DLLME coupled with GC-FID in the simultaneous determination of multiclass pesticides in vegetable samples. The parameters affecting the extraction efficiency of DLLME were studied and optimised.

\section{MATERIALS AND METHODS}

\section{Chemicals and standards solutions}

- Dispersive solvents (methanol, acetone and acetonitrile) and extraction solvents (dichloromethane, $\quad \mathrm{CH}_{2} \mathrm{Cl}_{2}$ and tetrachloroethylene, $\mathrm{C}_{2} \mathrm{Cl}_{4}$ ) used were of HPLC-grade except $\mathrm{C}_{2} \mathrm{Cl}_{4} \quad$ (Analytical Reagent grade, $99.97 \%$ ).

- Sodium chloride was of Guaranteed Reagent grade $(\geq 99.5 \%)$.

- Pesticide standards (diuron, alachlor, fenthion, fenitrothion and permethrin mixture) were more than $95 \%$ purity.

A range of standard mixture stock solutions containing 250-783 mg/L pesticides were prepared in acetone and stored at $4{ }^{\circ} \mathrm{C}$. Preparation of different concentration levels of the stock solutions was carried out to correspond to the sensitivity of the FID detector towards different compounds.
Working standard solutions of pesticides mixture were freshly prepared daily by serial dilution with acetone.

\section{Instrumentation}

The chromatographic analysis was performed on an Agilent 7890A model gas chromatography equipped with a split/ splitless injection inlet, flame ionization detector and a 7683 automatic liquid sampler. Analytes separation was conducted using a DB-35ms capillary column of $30 \mathrm{~m}, 0.32 \mathrm{~mm}$ i.d., $0.25 \mathrm{~m}$ film thickness (J\&W Scientific, CA, USA). Ultra pure helium gas $(99.9995 \%)$ was used as carrier gas at a flow rate of $1.5 \mathrm{~mL} / \mathrm{min}$. The injector temperature was $250{ }^{\circ} \mathrm{C}$ and all injections were made in split mode with a split ratio of 50:1. The oven temperature programme employed was as follows: initial oven temperature of $50{ }^{\circ} \mathrm{C}$, ramped to $190{ }^{\circ} \mathrm{C}$ at $40{ }^{\circ} \mathrm{C} / \mathrm{min}$ and hold for $1 \mathrm{~min} ; 190{ }^{\circ} \mathrm{C}$ to $300{ }^{\circ} \mathrm{C}$ at $20{ }^{\circ} \mathrm{C} / \mathrm{min}$ and hold for $4 \mathrm{~min}$. Total run time was $14 \mathrm{~min}$. The FID temperature was maintained at $300{ }^{\circ} \mathrm{C}$. The detector gases, air and hydrogen, were regulated at flow rates of 450 $\mathrm{mL} / \mathrm{min}$ and $40 \mathrm{~mL} / \mathrm{min}$ respectively. Agilent ChemStation software was used for instrumentalcontrolled and data analysis.

\section{Sample preparation}

Pesticide-free tomato and cucumber samples were bought from local supermarket. Individual vegetable sample was homogenised using a food processor with a 1:1 ratio of vegetable: distilled water. The homogenised sample was sieved and centrifuged at the speed of $4000 \mathrm{rpm}$ for $10 \mathrm{~min}$. The supernatant of the centrifuged mixture was filtered with Milipore $0.45 \mu \mathrm{m}$ pore size mixed cellulose esters membrane filters. The filtrate was then used in real sample analysis.

\section{DLLME analysis}

In DLLME method, $5.0 \mathrm{~mL}$ of sample solution was placed in a $10 \mathrm{~mL}$ screw cap conical bottom glass test tube and spiked with a mixture of pesticide standards at level A concentration $(1.75 \mathrm{mg} / \mathrm{L}$ diuron, $0.50 \mathrm{mg} / \mathrm{L}$ alachlor, $0.77 \mathrm{mg} / \mathrm{L}$ fenitrothion, $0.63 \mathrm{mg} / \mathrm{L}$ fenthion, $0.41 \mathrm{mg} / \mathrm{L}$ cis-permethrin and $1.08 \mathrm{mg} / \mathrm{L}$ trans-permethrin). A mixture of $0.8 \mathrm{~mL}$ acetone (as dispersive solvent) containing $14.2 \mu \mathrm{L}$ of tetrachloroethylene (as extraction solvent) was injected rapidly into the sample solution using a 1 $\mathrm{mL}$ syringe. The mixture was gently shaken and a cloudy 
solution was seen to form in the test tube. The mixture was then centrifuged for $3 \mathrm{~min}$ at $4000 \mathrm{rpm}$. The extraction solvent $(11.0 \pm 0.2 \mu \mathrm{L})$ was found to be sedimented at the bottom of the conical test tube after the centrifugation process. The sedimented extraction phase was extracted and transferred to a $100 \mu \mathrm{L}$ glass insert in a $2 \mathrm{~mL}$ glass vial for further instrumental analysis.

\section{Calculation of enrichment factor and extraction recovery}

Enrichment factor and extraction recovery were investigated under optimised experimental conditions. The following equations are used to calculate enrichment factor and extraction recovery [2].

$$
E F=\frac{C_{\text {sed }}}{C_{0}}
$$

where $\mathrm{EF}, \mathrm{C}_{\mathrm{sed}}$ and $\mathrm{C}_{\mathrm{o}}$ are the enrichment factor, concentration of analytes in sedimented phase and initial concentration of analyte in aqueous sample respectively.

$$
R \%=\frac{V_{\text {sed }} C_{\text {sed }}}{V_{a q} C_{0}}=E F \times \frac{V_{\text {sed }}}{V_{a q}} \times 100 \%
$$

where $\mathrm{R} \%, \mathrm{~V}_{\text {sed }}$ and $\mathrm{V}_{\mathrm{aq}}$ are the percent of extraction recovery, volume of sedimented phase and volume of aqueous sample respectively.

\section{RESULTS AND DISCUSSION}

\section{Optimisation of DLLME procedures}

To evaluate the efficiency of DLLME for the extraction of multipesticide residues from cucumber and tomato samples, parameters such as type and volume of extraction solvent, type and volume of dispersive solvent, extraction time and ionic strength of aqueous phase need to be optimized [5].

\section{Selection of extraction solvent}

Selecting the most suitable extraction solvent is one of the crucial steps in DLLME procedure to obtain satisfactory extraction efficiency. The selected extraction solvent should have (1) higher density than water, (2) low solubility in water,(3) high extraction capability of the interested analytes and(4) good chromatographic behaviour $[6,16]$. In order to fulfill the aim of green chemistry, extraction solvents considered in this study were as less hazardous to operator and environment as possible. Thus, two solvents $\left(\mathrm{C}_{2} \mathrm{Cl}_{4}\right.$ and $\left.\mathrm{CH}_{2} \mathrm{Cl}_{2}\right)$ were used in this study and their physical properties were shown in Table 1.A series of sample solutions were studied using $0.8 \mathrm{~mL}$ acetone containing different volume of extraction solvent to achieve $11.0 \pm 0.2 \mu \mathrm{L}$ of sedimented extraction phase. A volume of $14.2 \mu \mathrm{L}$ of $\mathrm{C}_{2} \mathrm{Cl}_{4}$ and $92.0 \mu \mathrm{L}$ of $\mathrm{CH}_{2} \mathrm{Cl}_{2}$ has proved to provide the optimum conditions. The average recovery (triplicate) and standard deviation (SD) for both extraction solvents were shown in Table 2. The results showed that both extraction recoveries for all the pesticides except diuron using $\mathrm{C}_{2} \mathrm{Cl}_{4}(76.6-103.9 \%)$ and $\mathrm{CH}_{2} \mathrm{Cl}_{2}$ (80.9-108.0\%) are high and within the acceptable range.

Table 1. Physical properties of extraction solvents.

\begin{tabular}{lllllll}
\hline Solvent & $\begin{array}{l}\text { Molecular formula } \\
\text { and weight }\end{array}$ & $\begin{array}{l}\text { Boiling Point } \\
\left({ }^{\circ} \mathrm{C}\right)\end{array}$ & $\begin{array}{l}\text { Vapor pressure } \\
(\mathrm{kPa} \text { at 20 }\end{array}$ & $\begin{array}{l}\log \mathrm{C}) \\
\mathrm{ow}\end{array}$ & $\begin{array}{l}\text { Density } \\
(\mathrm{g} / \mathrm{mL})\end{array}$ & $\begin{array}{l}\text { Solubility in } \\
100 \mathrm{~g} \text { of water }\end{array}$ \\
\hline $\begin{array}{l}\text { Dichloromethane } \\
\text { Tetrachloroethylene }\end{array}$ & $\mathrm{CH}_{2} \mathrm{Cl}_{2}, 84.93$ & 39.8 & 47 & 1.51 & 1.25 & 1.3 \\
$\mathrm{C}_{2} \mathrm{Cl}_{4}, 165.83$ & 121.1 & 1.7 & 3.4 & 1.62 & 0.015 \\
\hline
\end{tabular}


The recovery of diuron by using $\mathrm{CH}_{2} \mathrm{Cl}_{2}(27.9 \%)$ was higher than of $\mathrm{C}_{2} \mathrm{Cl}_{4}(6.0 \%)$, however, they were still far beyond the acceptable range (70\%$120 \%$ ). The low recoveries of diuron may due to the characteristic of this phenylurea compound which is thermally-labile and easily decomposed by high temperature. $\mathrm{C}_{2} \mathrm{Cl}_{4}$ was selected to be the most suitable extraction solvent for its high repeatability compared to $\mathrm{CH}_{2} \mathrm{Cl}_{2}$.
Low repeatability of $\mathrm{CH}_{2} \mathrm{Cl}_{2}$ is probably due to the low boiling point, high vapour pressure and solubility in water compare to $\mathrm{C}_{2} \mathrm{Cl}_{4}$ (Table 1). Higher solvent volatility represents higher probability of solvent loss due to evaporation during the extraction process. Together with a higher solubility in water compared to $\mathrm{C}_{2} \mathrm{Cl}_{4}$, both may lead to the change in the exact solvent volume involve in the extraction process [17].

Table 2. Efficiency of different extraction solvent evaluated for extraction of pesticides by DLLME ${ }^{\mathrm{a}}$.

\begin{tabular}{lcc}
\hline Compounds & Recovery $(\%) \pm \mathrm{SD}(n=3)$ \\
\cline { 2 - 3 } & Tetrachloroethylene & Dichloromethane \\
\hline Diuron & $6.0 \pm 0.3$ & $27.9 \pm 4.8$ \\
Alachlor & $76.6 \pm 2.0$ & $80.9 \pm 16.7$ \\
Fenitrothion & $97.3 \pm 3.4$ & $89.5 \pm 16.6$ \\
Fenthion & $103.9 \pm 2.5$ & $96.6 \pm 16.9$ \\
cis-Permethrin & $99.1 \pm 4.4$ & $108.0 \pm 23.5$ \\
trans-Permethrin & $100.4 \pm 4.2$ & $92.4 \pm 19.9$ \\
\hline
\end{tabular}

${ }^{a}$ Extraction condition: water sample, $5.0 \mathrm{~mL}$; dispersive solvent (acetone) volume, $0.8 \mathrm{~mL}$; extraction solvent volume, $14.2 \mu \mathrm{L} \mathrm{C}_{2} \mathrm{Cl}_{4}, 92.0 \mu \mathrm{L} \mathrm{CH}_{2} \mathrm{Cl}_{2}$; sedimented phase volume, $11.0 \pm 0.2 \mu \mathrm{L}$; concentration of pesticides: diuron $(1.75 \mathrm{mg} / \mathrm{L})$, alachlor $(0.50 \mathrm{mg} / \mathrm{L})$, fenthion $(0.77 \mathrm{mg} / \mathrm{L})$, fenitrothion $(0.63 \mathrm{mg} / \mathrm{L})$, cis-permethrin $(0.41$ $\mathrm{mg} / \mathrm{L})$ and trans-permethrin $(1.08 \mathrm{mg} / \mathrm{L})$.

\section{Selection of dispersive solvent}

A suitable dispersive solvent should be miscible in both sample solution and extraction solvent. Acetone, methanol and acetonitrile which possess this characteristic were investigated in this study. When different dispersive solvents are employed with constant volume of extraction solvent, the volume of sedimented phase often changes [18-19]. Thus, a series of sample solutions were studied using $0.8 \mathrm{~mL}$ of acetone, methanol and acetonitrile containing $14.2 \mu \mathrm{L}, 14.7 \mu \mathrm{L}$ and $14.5 \mu \mathrm{L}$ of $\mathrm{C}_{2} \mathrm{Cl}_{4}$ (as extraction solvent), respectively. The volume of dispersive solvent changed simultaneously with the type of dispersive solvent used to ensure a constant volume of settled phase $(11.0 \pm 0.2 \mu \mathrm{L})$ being obtained. The extraction recoveries for all the pesticides except diuron by using acetone, methanol and acetonitrile were ranged $76.6-103.9 \%, 80.5-$ $119.6 \%$, and $70.6-103.6 \%$, respectively. The recoveries of all the three dispersive solvents were within the acceptable range and showed no remarkable variations. However, acetone showed higher repeatability (\% RSD ranging from $0.3-4.4$ ) compared to methanol (\% RSD ranging from 0.57.4) and acetonitrile (\% RSD ranging from 0.049.4). Besides, acetone also has the lowest toxicity among the other two dispersive solvents as well as low cost. Thus, acetone was selected as the optimal dispersive solvent to be used in subsequent experiments.

\section{Selection of extraction solvent volume}

To study the effect of extraction solvent volume on the extraction efficiency, experimental conditions were set constant with $0.8 \mathrm{~mL}$ of acetone containing different volumes of $\mathrm{C}_{2} \mathrm{Cl}_{4}(13.0,14.2,15.0,20.0$, $25.0 \mu \mathrm{L}$ ). The results, based on triplicate analyses, showed that by increasing the volume of $\mathrm{C}_{2} \mathrm{Cl}_{4}$ from $13.0 \mu \mathrm{L}$ to $25.0 \mu \mathrm{L}$, the volume of sedimented phase increased from $10.4 \mu \mathrm{L}$ to $20.7 \mu \mathrm{L}$. The effect of extraction solvent volume on recoveries and enrichment factors of pesticides obtained from DLLME were represented in Figure 1 and Figure 2 respectively. 


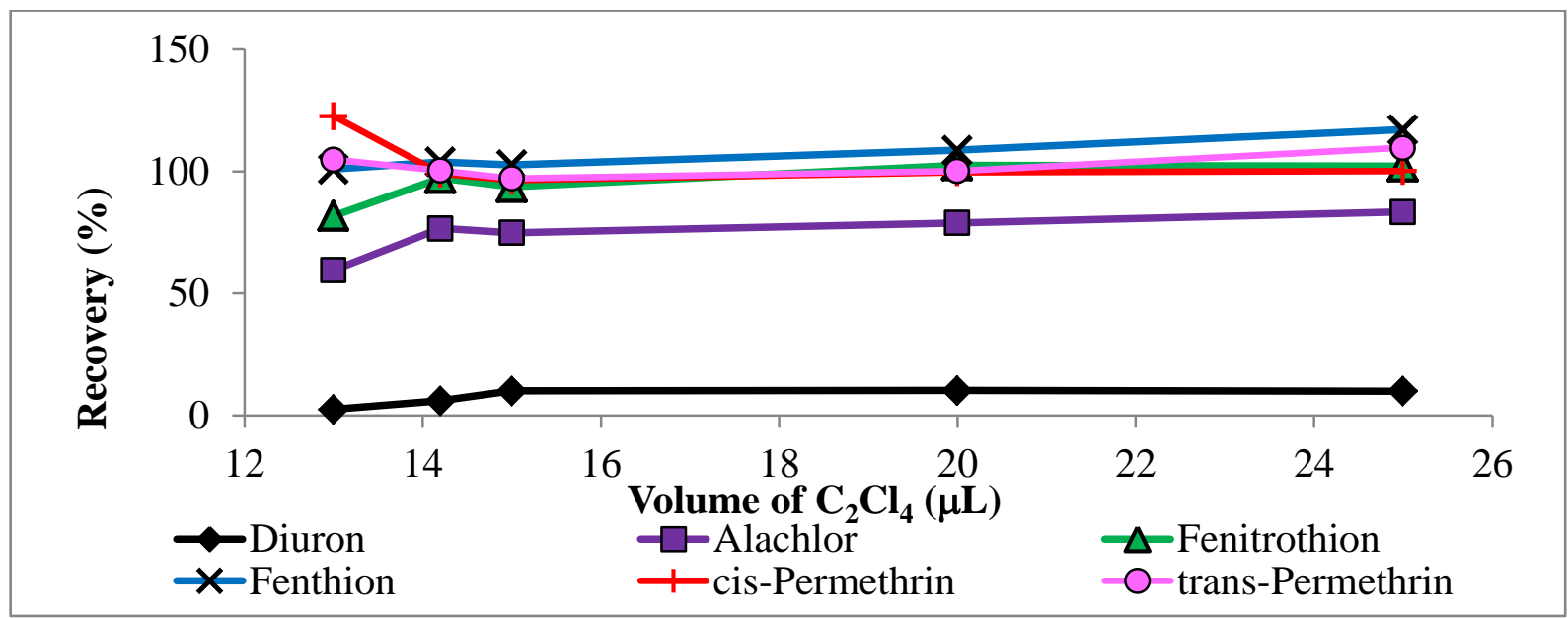

Figure 1. Effect of extraction solvent $\left(\mathrm{C}_{2} \mathrm{Cl}_{4}\right)$ volume on the recoveries of pesticides obtained from DLLME.

Extraction conditions: water sample, $5.0 \mathrm{~mL}$; dispersive solvent (acetone) volume, $0.8 \mathrm{~mL}$; concentration of pesticides: diuron $(1.75 \mathrm{mg} / \mathrm{L})$, alachlor $(0.50 \mathrm{mg} / \mathrm{L})$, fenthion $(0.77 \mathrm{mg} / \mathrm{L})$, fenitrothion $(0.63 \mathrm{mg} / \mathrm{L})$, cispermethrin $(0.41 \mathrm{mg} / \mathrm{L})$ and trans-permethrin $(1.08 \mathrm{mg} / \mathrm{L})$.

As can be seen in Figure 1, recoveries of all pesticides except diuron were in the acceptable range (70\%-120\%) when $14.2 \mu \mathrm{L}-25.0 \mu \mathrm{L}$ of $\mathrm{C}_{2} \mathrm{Cl}_{4}$ was used in this study. Overall, the recoveries were seen to have slightly increased with the increasing volume of $\mathrm{C}_{2} \mathrm{Cl}_{4}$. However, the enrichment factors have shown to decrease dramatically when the volume of $\mathrm{C}_{2} \mathrm{Cl}_{4}$ increased from $14.2 \mu \mathrm{L}$ to $25.0 \mu \mathrm{L}$ (Figure 2).
This was due to the increasing volume of sedimented phase and thus lowering the concentration of extracted analytes in it due to dilution effect [20]. As a result, $14.2 \mu \mathrm{L}$ of $\mathrm{C}_{2} \mathrm{Cl}_{4}$ was selected as optimal volume of extraction solvent since volume of extraction solvent less than 14.2 $\mu \mathrm{L}$ may cause insufficient settled phase volume for GC analysis by automatic injection.

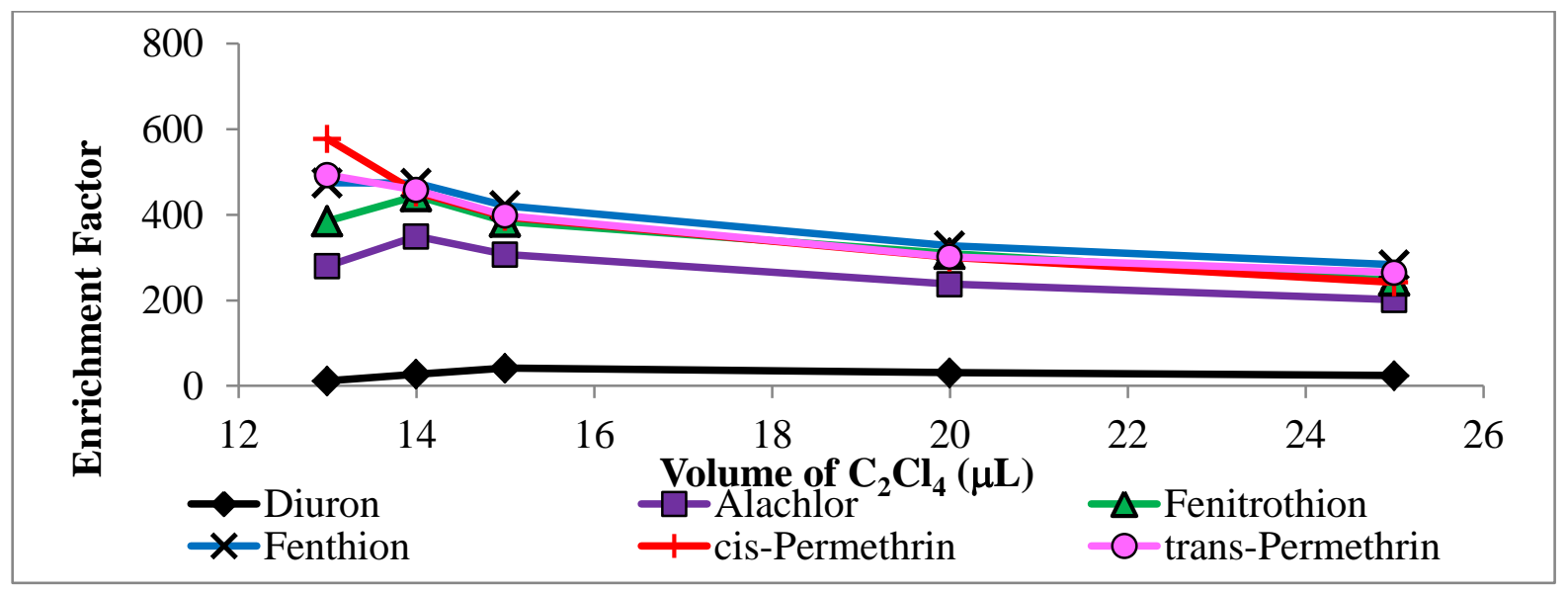

Figure 2. Effect of extraction solvent $\left(\mathrm{C}_{2} \mathrm{Cl}_{4}\right)$ volume on the enrichment factor of pesticides obtained from DLLME.

Extraction conditions: water sample, $5.0 \mathrm{~mL}$; dispersive solvent (acetone) volume, $0.8 \mathrm{~mL}$; concentration of pesticides: diuron $(1.75 \mathrm{mg} / \mathrm{L})$, alachlor $(0.50 \mathrm{mg} / \mathrm{L})$, fenthion $(0.77 \mathrm{mg} / \mathrm{L})$, fenitrothion $(0.63 \mathrm{mg} / \mathrm{L})$, cispermethrin $(0.41 \mathrm{mg} / \mathrm{L})$ and trans-permethrin $(1.08 \mathrm{mg} / \mathrm{L})$. 


\section{Selection of dispersive solvent volume}

Optimizing the volume of dispersive solvent used in DLLME is essential because variation in volume may cause the volume change of sedimented phase although with the use of constant volume of extraction solvent. Thus, to avoid this matter and to obtain a constant volume of sedimented phase (11.0 $\pm 0.2 \mu \mathrm{L}$ ), the volume of acetone and $\mathrm{C}_{2} \mathrm{Cl}_{4}$ were changed simultaneously in this study [5]. The effect of dispersive solvent volume on the extraction efficiency was studied by performing experiments with vary volume of acetone $(0.6,0.8,1.0,1.5,2.0$ $\mathrm{mL}$ ) containing $14.1,14.2,14.4,15.2,16.5 \mu \mathrm{L}$ of $\mathrm{C}_{2} \mathrm{Cl}_{4}$, respectively. Triplicate analyses were carried out and the effect of dispersive solvent volume on the extraction recoveries was represented in (Figure $3)$.

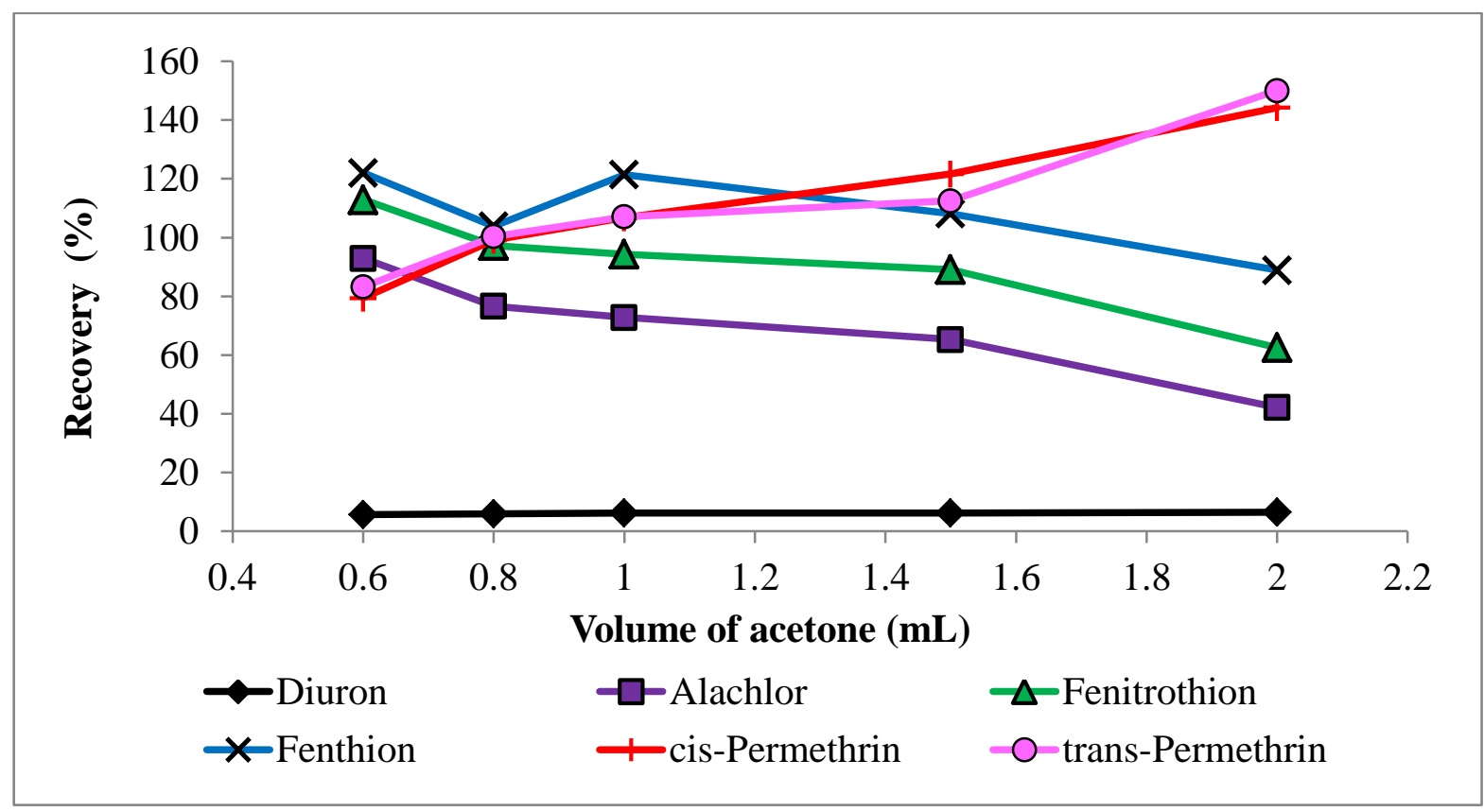

Figure 3. Effect of dispersive solvent (acetone) volume on the extraction recoveries of pesticides obtained from DLLME.

Extraction conditions: water sample, $5.0 \mathrm{~mL}$; extraction solvent $\left(\mathrm{C}_{2} \mathrm{Cl}_{4}\right)$ volume, $14.2 \mu \mathrm{L}$; concentration of pesticides: diuron $(1.75 \mathrm{mg} / \mathrm{L})$, alachlor $(0.50 \mathrm{mg} / \mathrm{L})$, fenthion $(0.77 \mathrm{mg} / \mathrm{L})$, fenitrothion $(0.63 \mathrm{mg} / \mathrm{L})$, cispermethrin $(0.41 \mathrm{mg} / \mathrm{L})$ and trans-permethrin $(1.08 \mathrm{mg} / \mathrm{L})$.

According to Fig 3, increasing volume of acetone has caused the extraction recoveries of alachlor, fenthion and fenitrothion to decrease while cis, trans-permethrin increased. Alachlor, fenthion and fenitrothion which were pronounced to be the more polar ones with lower octanol/water partition coefficient ( $\left.\log _{10} \mathrm{~K}_{\mathrm{OW}}\right)$ (Table 3 ), showed decreasing extraction recoveries when increasing acetone volume was used. This may due to the increased solubility of these three pesticides in the aqueous phase as more dispersive solvent has been added and thus led to a decrease in the analyte distribution coefficient in the extraction phase. However, for cis, trans-permethrin with higher $\log _{10} \mathrm{~K}_{\mathrm{OW}}$ (Table 3), the increasing volume of $\mathrm{C}_{2} \mathrm{Cl}_{4}$ used due to the increasing acetone volume may has led to the recoveries increased of cis, transpermethrin. To obtain pesticide recoveries within the acceptable range $(70-120 \%), 0.8 \mathrm{~mL}$ of acetone was used in subsequent experiments. 
Table 3. List of pesticides classes, chemical group, $\log \mathrm{K}_{\mathrm{ow}}$ and their maximum residue levels.

\begin{tabular}{lllccc}
\hline Pesticides & $\begin{array}{c}\text { Classes of } \\
\text { pesticides }\end{array}$ & Chemical group & $\log \mathrm{K}_{\mathrm{ow}}{ }^{\mathrm{a}}$ & $\begin{array}{c}\text { EU MRLs }{ }^{\mathrm{b}} \\
(\mathrm{mg} / \mathrm{kg})\end{array}$ & $\begin{array}{c}\text { CODEX MRLs }{ }^{\mathrm{c}} \\
(\mathrm{mg} / \mathrm{kg})\end{array}$ \\
\hline Diuron & Herbicide & Phenylurea & 2.6 & 0.1 & - \\
Alachlor & Herbicide & Chloroacetamide & 3.5 & 0.1 & 1 \\
Fenitrothion & Insecticide & Organophosphorus & 3.3 & 0.01 & 0.05 \\
$\begin{array}{l}\text { Fenthion } \\
\text { Cis, trans-permethrin }\end{array}$ & $\begin{array}{l}\text { Insecticide } \\
\text { Insecticide }\end{array}$ & $\begin{array}{l}\text { Organophosphorus } \\
\text { Pyrethroid }\end{array}$ & 6.1 & 0.01 & 1 (tomato); \\
& & & 6.5 & 0.05 & 0.5 (cucumber) \\
\hline
\end{tabular}

a obtained from (http://www.sigmaaldrich.com/safety-center.html, accessed Oct 2011).

b obtained from (http://ec.europa.eu/sanco_pesticides/public/index.cfm?event=substance.selection\&ch=1, accessed Nov 2011).

${ }^{\mathrm{c}}$ obtained from (http://www.codexalimentarius.net/pestres/data/index.html. Accessed on 25 May 2012).

\section{Effect of extraction time}

In DLLME, the extraction time was defined as the time interval between the injection of mixture of dispersive solvent (acetone) and extraction solvent $\left(\mathrm{C}_{2} \mathrm{Cl}_{4}\right)$, and before the centrifugation process [6]. The results showed that there was no significant difference in the extraction recoveries for all the pesticides during the investigated extraction time range ( $20 \mathrm{~s}, 5 \mathrm{~min}, 15 \mathrm{~min}, 30 \mathrm{~min}$ and $60 \mathrm{~min}$ ). This has proved that the distribution equilibrium of analytes has been reached within seconds [5]. The formation of cloudy solution has provided an infinitely large surface area for mass transfer from the aqueous phase to the extraction phase and this has caused the equilibrium to be achieved quickly. Very short extraction time required in DLLME is one of the most remarkable advantages of DLLME. Thus, the optimal extraction time for subsequent experiments was fixed at $20 \mathrm{~s}$.

\section{Effect of ionic strength}

In the study of ionic strength, effect of ionic strength was evaluated by carrying out DLLME procedure with the addition of different percentage of sodium chloride $(\mathrm{NaCl})$ in the range of $0-5 \%(\mathrm{w} / \mathrm{v})$ into the sample solution before the injection of solvents mixture. Results showed that when the percentage of sodium chloride increased from 0 to $5 \%$, the volume of sedimented phase increased from 11.0 to $11.9 \mu \mathrm{L}$ due to the decrease of extraction solvent aqueous solubility in the presence of salt. The addition of salt has no influence on the extraction efficiency of all the pesticides and this has proved that the extraction is quantitative. However, there were slight decreases in the enrichment factor values with the addition of salt into the aqueous sample. Therefore, no salt was added into the aqueous sample in subsequent experiments.

\section{Analytical performance}

The optimized DLLME conditions are as follow: $5.0 \mathrm{~mL}$ sample solution, $0.8 \mathrm{~mL}$ acetone (as dispersive solvent) containing $14.2 \mu \mathrm{L} \mathrm{C}_{2} \mathrm{Cl}_{4}$ (as extraction solvent), without addition of salt, centrifuge at $4000 \mathrm{rpm}$ for $3 \mathrm{~min}$ at room temperature. To validate the optimized DLLME conditions, linearity, repeatability in terms of intraday precision and inter-day precision, enrichment factor and limit of detections (LODs) were investigated and listed in (Table 4). 
Table 4. Quantitative result of pesticides by DLLME ${ }^{\mathrm{a}}$.

\begin{tabular}{|c|c|c|c|c|c|c|c|c|}
\hline \multirow[t]{2}{*}{ Pesticides } & \multirow[t]{2}{*}{$E F^{\mathrm{b}}$} & \multirow{2}{*}{$\begin{array}{c}\mathrm{LR}^{\mathrm{c}} \\
(\mu \mathrm{g} / \mathrm{L})\end{array}$} & \multirow[t]{2}{*}{$R^{2 \mathrm{~d}}$} & \multirow{2}{*}{$\begin{array}{l}\mathrm{LOD}^{\mathrm{e}} \\
(\mu \mathrm{g} / \mathrm{L})\end{array}$} & \multicolumn{3}{|c|}{ Intra-day RSD (\%) ${ }^{\mathrm{f}}$} & \multirow{2}{*}{$\begin{array}{c}\text { Inter-day RSD } \\
(\%)^{\mathrm{g}} \\
(\mathrm{n}=3)\end{array}$} \\
\hline & & & & & $\begin{array}{c}\text { level A } \\
(\mathrm{n}=6)\end{array}$ & $\begin{array}{c}\text { Level B } \\
(\mathrm{n}=6)\end{array}$ & $\begin{array}{c}\text { Level C } \\
(n=6)\end{array}$ & \\
\hline Diuron & 29 & $350-3500$ & 0.9966 & 560 & 14.2 & 15.7 & 8.3 & 13.9 \\
\hline Alachlor & 366 & $8-2000$ & 0.9988 & 3 & 3.9 & 3.8 & 6.1 & 3.9 \\
\hline Fenitrothion & 452 & $10-3100$ & 0.9992 & 3.5 & 3.4 & 3.9 & 6.4 & 3.9 \\
\hline Fenthion & 476 & $8-2500$ & 0.9993 & 3 & 3.6 & 4.4 & 7.4 & 4.0 \\
\hline cis-Permethrin & 447 & $16-1650$ & 0.9984 & 4.5 & 2.3 & 5.4 & 7.2 & 4.6 \\
\hline trans-Permethrin & 455 & $43-4300$ & 0.9982 & 8.5 & 3.1 & 4.9 & 6.2 & 4.6 \\
\hline
\end{tabular}

${ }^{a}$ Extraction condition: water sample volume, $5.00 \mathrm{~mL}$; dispersive solvent (acetone) volume, $0.80 \mathrm{~mL}$; extraction solvent $\left(\mathrm{C}_{2} \mathrm{Cl}_{4}\right)$ volume, $14.2 \mu \mathrm{L}$; sedimented phase volume, $11 \pm 0.2 \mu \mathrm{L}$; room temperature.

${ }^{\mathrm{b}} \mathrm{EF}$, enrichment factor.

${ }^{\mathrm{c}} \mathrm{LR}$, linear range.

${ }^{\mathrm{d}} R^{2}$, coefficient of determination.

${ }^{\mathrm{e}} \mathrm{LOD}$, limit of detection.

${ }^{\mathrm{f}}$ Intra-day RSD (\%), relative standard deviation at pesticides concentration level B $=1 / 5$ level A; level C = 1/10 level A.

${ }^{\mathrm{g}}$ Inter-day RSD (\%), relative standard deviation at pesticides concentration level B.

The linearity of the method was tested by plotting calibration curves of analyte peak area versus concentration of each pesticide. Each calibration curve includes 6 points of concentration level within $80-120 \%$ of the expected concentration range with 3 replicates for each concentration level. Good linearity was observed for all the pesticides with coefficients of determination $\left(\mathrm{R}^{2}\right)$ more than 0.996. The RSD of each concentration level was always less than $10 \%$ for all the pesticides except diuron which showed RSD less than $20 \%$.

The repeatability of the proposed DLLME method was investigated in terms of intra-day precision and inter-day precision as RSD values. Intra-day precision was calculated by analyzing six replicates of sample extracts spiked at three concentration levels (level A, level B (1/5 level A) and level C $(1 / 10$ level A)). The RSD values obtained were ranged from $2 \%$ to $16 \%$ with lower RSD values observed at higher pesticides concentration level except diuron. Similar response was observed in other researchers' works too [21]. RSD of diuron were higher ( $8 \%$ to $16 \%$ ) compared to other pesticides, this may due to instability of diuron at high temperature during $\mathrm{GC}$ analysis, thus causing low repeatability. Inter-day precision was evaluated at level $\mathrm{B}$ pesticides mixture concentration in triplicates for three different days in a week. The RSD values were almost similar or slightly lower than the intra-day precision RSD values at level B pesticide concentration. This has proved that the proposed method was stable.

The enrichment factors of pesticides obtained by proposed optimized DLLME method were high except for diuron (Table 2). Limit of detection was determined by analyzing blank samples spiked with decreasing concentration of pesticides mixture until a signal-to-noise ratio of 3:1 was achieved. The results showed that the LOD values for all the pesticides except diuron $(560 \mu \mathrm{g} / \mathrm{L})$ were range from $3-8.5 \mu \mathrm{g} / \mathrm{L}$ and they were considered good for pesticides analysis using a GC equipped with FID detector. 


\section{Real sample analysis}

In order to evaluate the pesticide extraction efficiency of the proposed DLLME method in real samples, tomato and cucumber samples with a dilution factor of 1: 25 were spiked at pesticide concentration level C (1/10 level A).Matrixmatched calibration standards were used to minimize matrix effect.The results were reported in terms of relative recovery (RR\%) which was defined as the percentage ratios of the concentration of analytes found to the concentration of analytes spiked. RR\% was calculated according to the following equation:

$$
\mathrm{RR} \%=\frac{\mathrm{C}_{\text {found }}}{\mathrm{C}_{\text {initial }}} \times 100
$$

where $\mathrm{C}_{\text {found }}$ is obtained from the calibration curves. The concentration level was prepared in triplicate and the relative standard deviations were calculated too. Based on the results, the relative recoveries of pesticides from tomato and cucumber extracts were in the range of $94.58-103.34 \%$ and $96.46-109.45 \%$ respectively which were within the acceptable range.

The LODs of pesticides extracted from both commodities were determined by analyzing sample solutions (with a dilution factor of 1:25) spiked with decreasing concentration of pesticides mixture until a peak height of three times higher than the noise level was achieved. The LODs of all pesticides except diuron from tomato and cucumber extracts were ranged from $7.5-15 \mu \mathrm{g} / \mathrm{L}$ and $15-39 \mu \mathrm{g} / \mathrm{L}$ respectively. All the LODs of pesticides except diuron extracted from both tomato and cucumber extracts using the proposed DLLME method coupled with GC-FID were still found to be lower than the maximum residue levels (MRLs) established by European Union and / or Codex Alimentarius.

\section{CONCLUSION}

In this study, DLLME coupled with GC-FID has been used for the analysis of different chemical group pesticides in tomato and cucumber samples. The proposed method provided good recoveries, enrichment factor and repeatability. The LODs of pesticides obtained were still compatible with the MRLs established by EU or CODEX Alimentarius despite of the use of FID detector. Even with the necessity of sample preparation procedures, the analysis time was considered relatively short due to the fast achievement of distribution equilibrium which has known to be one of the key advantages of DLLME. The result of this study has shown to offer an alternative approach for pesticides analysis on vegetables using DLLME coupled with GC-FID.

\section{ACKNOWLEDGEMENT}

The authors would like to thank the Ministry of Higher Education of Malaysia (Fundamental Research Grant no. FRGS/1/10/SG/UNITEN/02/4) and Universiti Tenaga National (Grant no. J510050308) for the financial supports.

\section{REFERENCES}

1. Tsai W. C. and Huang S. D. (2009). Dispersive liquid-liquid microextraction with little solvent consumption combined with gas chromatography-mass spectrometry for the pretreatment of organochlorine pesticides in aqueous samples. Journal of Chromatography A 1216: 5171-5175.

2. Chai M.K. and Tan G.H. (2009). Validation of a headspace solid-phase microextraction with an internal standard method for the determination of pesticide residues in fruits and vegetables. Food Chemistry 117: 561567.

3. Lopez-Blanco M. C., Blanco-Cid S., CanchoGrande B. and Simal-Gandara J. (2003). Application of single drop microextraction and comparison with solid phase microextraction and solid phase extraction for the determination of alpha and beta endosulfan in water samples by gas chromatography electron capture detection. Journal of Chromatography A 984: 245-252.

4. Basheer C., Lee H. K. and Obbard J.P. (2002). Determination of organochlorine pesticides in seawater using liquid-phase hollow fibre membran microextraction and gas chromatography-mass spectrometry. Journal of Chromatography A 968: 191-199.

5. Rezaee M., Assadi Y, Milani Hosseini M. R., Aghaee E., Ahmadi F. and Berijani S. (2006). Determination of organic compounds in water using dispersive liquid-liquid microextraction. Journal of Chromatography A 1116: 1-9.

6. Berijani S., Assadi Y., Anbia M., Rezaee M., Milani Hosseini R. M. and Aghaee E. (2006). Dispersive liquid-liquid microextraction 
combined with gas chromatography-flame hotometric detection: Very simple, rapid and sensitive method for the determination of organanophophorus pesticides in water. Journal Chromatography A 1123: 1-9.

7. Xu H., Ding Z. Q., Lv L. L., Song D. D. and Feng Y. Q. (2009). A novel dispersive liquid-liquid microextraction based on solidification of floating organic droplet method for determination of polycyclic aromatic hydrocarbons in aqueous samples. Analytical Chimica Acta 636: 28-33.

8. Zhao X. N., Fu L. Y., Hu J., Li J. W., Wang H. L., Huang C. J. and Wang X. D. (2009). Analysis of PAHs in Water and Fruit Juice Samples by DLLME Combined with LCFluorescence Detection. Chromatographia 69: 1384-1388.

9. Rezaei F., Bidari A., Birjandi A. P., Hosseini M. R. M. and Assadi Y. (2008). Development of a dispersive liquid-liquid microextraction method for the determination of polychlorinated biphenyls in water. Journal of Hazardous Materials 158: 621627.

10. Hu J., Fu L. Y., Zhao X. N., Liu X. J., Wang H. L., Wang X. D. and Dai L. Y. (2009). Dispersive liquid-liquid microextraction combined with gas chromatography-electron capture detection for the determination of polychlorinated biphenyls in soils. Analytical Chimica Acta 640: 100-105.

11. Sarafraz-Yazdi, A., Razavi, N., \& Raouf Yazdinejad, S. (2008). Separation and determination of amitriptyline and nortriptyline by dispersive liquid-liquid microextraction combined with gas chromatography flame ionization detection. Talanta 75: 1293-1299.

12. Chen H., Chen H., Ying J., Huang J. and Liao L. (2009). Dispersive liquid-liquid microextraction followed by highperformance liquid chromatography as an efficient and sensitive technique for simultaneous determination of chloramphenicol and thiamphenicol in honey. Analytical Chimica Acta 632: 80-85.

13. Cruz-Vera M., Lucena R., Cárdenas S. and Valcárcel M. (2009). One-step in-syringe ionic liquid-based dispersive liquid-liquid microextraction. Journal of Chromatography A 1216: 6459-6465.

14. Nagaraju D. and Huang S. (2007). Determination of triazine herbicides in aqueous samples by dispersive liquid-liquid microextraction with gas chromatographyion trap mass spectrometry. Journal of Chromatography A 1161: 89-97.

15. Moinfar S. and Hosseini M. R. M. (2009). Development of dispersive liquid-liquid microextraction method for the analysis of organophosphorus pesticides in tea. Journal of Hazardous Materials 169: 907-911.

16. Melwanki M.B. and Fuh M. R. (2008). Partitioned dispersive liquid-liquid microextraction: An approach for polar organic compounds extraction from aqueous samples. Journal of Chromatography A 1207: 24-28.

17. Maštovská K. and Lehotay S. J. (2004). Evaluation of common organic solvents for gas chromatographic analysis and stability of multiclass pesticide residues. Journal of Chromatography A 1040: 259-272.

18. Liang P., Xu J. and Li Q. (2008). Application of dispersive liquid-liquid microextraction and high-performance liquid chromatography for the determination of three phthalate esters in water samples. Analytica Chimica Acta 609: 53-58.

19. Fu L. Y., Liu X. J., Hu J., Zhao, X. N., Wang H. L. and Wang X. D. (2009). Application of dispersive liquid-liquid microextraction for the analysis of triazophos and carbaryl pesticides in water and fruit juice samples. Analytica Chimica Acta 632: 289-295.

20. Pusvakiene E., Januskevic B., Prichodko A. and Vickackaite V. (2009). Simultaneous derivatization and dispersive liquid-liquid microextraction for fatty acid GC determination in water. Chromatographia 69: 271-276.

21. Cunha S. C., Fernandes J. O. and Oliveira M. B. P. P. (2009). Fast analysis of multiple pesticide residues in apple juice using dispersive liquid-liquid microextraction and multidimensional gas chromatography-mass spectrometry. Journal of Chromatography A 1216: 8835-8844. 